\title{
INTEGRATED ASSESSMENT OF BUILDINGS QUALITY IN THE CONTEXT OF SUSTAINABLE DEVELOPMENT PRINCIPLES
}

\author{
DOI: 10.12776/QIP.V18I2.383
}

\author{
MÁRIA KOZLOVSKÁ, ZUZANA STRUKOVÁ, ALENA TAŽIKOVÁ
}

Received 2 September 2014, Revised 16 September 2014, Accepted 22 November 2014

\section{INTRODUCTION}

"Our efforts to be a leader in sustainability is one of fundamental values of our company. As leaders in sustainability, we are trying to promote the new solutions for sustainable development, while continuing in responsible development of our activities and aiming at increasing economic results." (Sustainability/Corporate social responsibility in Henkel)

"What we do today, affects the world in which we will live tomorrow. That is why the company T-Systems is committed to the principle of sustainable development. While pursuing our business goals, we concern in wise and sparing exploitation of resources." (T-Systems)

... also in Slovakia, various companies increasingly „,converted” their in public presented visions from certified management systems to philosophy of sustainability.

The terms sustainability and sustainable development began to be used in the beginning of 1970's. Increasingly, the terms began to be used in connection with one-sided preference to the pro-growth politics and strategies, the implementation of which peaked during the 1980's. In the late 1980's, the term has already been established in the approaches which were based on the fact that uncontrollable (e.g. economic, business and demographic) growth is unsustainable, as the resources to support this growth are limited. The World Commission on Environment and Development defined in 1987 the sustainable development - as the development that meets the needs of the present without compromising the ability of future generations to meet their own needs.

The Conference of United Nations Organisation, centred on living environment and development, held in 1992 in Rio de Janeiro, declared by its document AGENDA 21 the fundamental support of sustainable development. 
Consequently, this support was reaffirmed and declared in the final documents adopted at the World Summit on Sustainable Development in Johannesburg, 2002. In 2010, the document Europe 2020: A European Strategy for Smart, Sustainable and Inclusive Growth was adopted. The goal of the strategy was to emerge from the crisis and to prepare the European Union economy for the next decade. One of the five main objectives, known as "20/20/20" (reducing greenhouse gas emissions by at least $20 \%$ compared to 1990 levels, increasing renewable resources in final energy consumption by $20 \%$ and improving energy efficiency by 20\%), significantly reflected in construction industry and in sustainable construction. The studies have demonstrated the possible interactions among the three European objectives (Stankeviciute and Criqui, 2008), with emphasis on $\mathrm{CO}_{2}$ emissions reducing and decarbonisation of all products, services and technologies (Tasios, et al., 2013). After more than 20 years, the contributions of the initiative, demonstrating in better environmental protection awareness, have been studied at national levels (Květoň, et al., 2014).

Buildings and their operation fall into main consumers of material and energetic resources, while belong to major polluters of environment. It is well known that the building in developed countries accounts for about 30 to $40 \%$ of all energy consumption and are equally responsible for creation of $\mathrm{CO}_{2}$ emissions, waste and other pollution, depending on the building type, its location or utilisation of renewable resources (Heinonen and Junnila, 2014).

So, looking for new technologies, using the new progressive material and design solutions that lead towards improving the construction, not only from economic but also from environmental and socio-cultural point of view, represent a huge potential in terms of ensuring the requirements of sustainable society development. Recently, there are more than 60 systems for assessment of building sustainability that are based on the three mentioned aspects. The assessment systems are summarized and compared in several research studies (Ding, 2008; Haapio and Viitaniemi, 2008; Sharifi and Murayama, 2013; Singh, et al., 2012).

Although the first assessment systems in the area of the building sustainability started to be used more than 20 years ago, the requirements development as well as development of the systems supporting their consideration creates conditions for their continual development. According to several research studies (Cole, 2005; CESBA, 2014), it is necessary to reconfigure the systems for easier and more practical using. The definite objective of their continual development consist in improving the quality of buildings using, taking into account the economic, environmental and social aspects of sustainable development of the all society and the life on Earth.

The quality of the building is directly proportional to quality of life in the building. However, the cost of green building is not at the present markedly higher when comparing to traditional building. In the past twenty years, several studies and practical examples have indicated that the effective design and construction of green buildings can also be achieved with minimal increase in the 
cost. According to Kim et al. (2014), the incorporation of green systems causes the construction costs to increase by $10 \%$ more than the traditional building. The study conducted in our institute, realized in segment of low-energy family houses in Slovakia (Župová and Kozlovská, 2013) indicated that the initial cost of the family house, classified in a higher energy standard which can save about $60 \%$ energy, is the comparable to the same house built in the traditional standard.

The aim of the paper is to analyse the assumptions for integrated assessment of buildings quality in the context of sustainable development principles and to contribute for a serious research task - demonstration of sustainability principles impact on living quality through case study.

\section{RESEARCH METHODOLOGY}

The paper provides a general review and a genesis of "sustainability" phenomenon in the context of sustainable development of the whole society as well as in the context of construction sustainability issues. It analyses the certification systems that assess buildings sustainability within wider environmental, economic and social relations. An effort to increase the quality of construction and to provide objectified assessment with measurable and comparable results has evoked the origin and development of the tools for buildings sustainability assessment. All global knowledge and approaches to the issue are studied in the national environment.

In the case study, there are analysed the approaches into assessment of one from few certified sustainable projects in Slovakia "EcoPoint Office Center Kosice".

The results are destined for potential investors perhaps even for present owners that have ambitions and responsibility for building sustainability principles performance when designing and using their properties. The approach into process of buildings sustainability not only from certification but also from the real benefits of the buildings sustainability point of view is mentioned in the paper.

\subsection{The Principles of Sustainable Development}

In Slovakia, the first set of sustainable development indicators was approved by the Government Resolution in 1997 and the National Strategy for Sustainable Development of the Slovak Republic was adopted in 2001. In this strategic document, the sustainable development is defined as "goal-directed, long-term (continuous), complex and synergistic process, influencing conditions and all aspects of life (cultural, social, economic, environmental and institutional) at all levels (local, regional, global) and destined towards a functional model of a certain community (local and regional community, country, international community) which meets in good manner the biological, material, spiritual and social needs and people interests, while eliminating or significantly reducing the interventions that threaten, damage or destroy conditions and forms of life, doesn't load above the country, uses its resources wisely and protects cultural 
and natural heritage." The assessment of sustainability is based on the following fundamental principles:

- the principle of supporting the human resource development,

- the ecological principle,

- the principle of efficiency,

- the principle of self - regulation and self-supporting development,

- the principle of reasonable sufficiency,

- the principle of preventive care and predictability,

- the principle of respecting the needs and rights of future generations,

- the principle of intra-generational, inter-generational and global equality of Earth inhabitants rights,

- the principle of cultural and social integrity,

- the principle of non-violence,

- the principle of emancipation and participation,

- the principle of solidarity,

- the principle of subsidiarity,

- the principle of acceptable errors,

- the principle of optimization,

- the principle of socially, ethically and environmentally friendly economy, decision making, management and behaviour.

\subsection{The Parallels of Construction Sustainability and Quality}

At the present, the quality of construction is characterized by the fact if the building is sustainable (word "green" is often used as synonym) with emphasis on responsibility for society and environment. The sustainable (green) building must be in compliance with the key characteristics of the building, expressing the quality of planning process, as optimization of environmental, economic and social parameters of the quality. All arguments of sustainability are beneficial for the demand for construction quality. Higher initial cost of green buildings could be returned to owner many times, due to these buildings energy performance and efficiency as well as their positive impact on health, welfare and productivity of buildings users.

In the long term, it is appropriate to focus on good-class building materials which play an important role in superior construction and using of constructed building. The most advanced materials and technologies present an added value which can bring some additional savings during the building life cycle and higher initial investment could be returned in the first energy bill. When purchasing building materials, the quality is a key factor for $82 \%$ of Slovaks, while $91 \%$ of them are disposed to pay extra for it. This is the result of a survey conducted by STEM/MARK agency in November 2013 in Slovakia. The results of the survey unveiled that Slovaks are dissatisfied with the overall quality of buildings constructed recently in Slovakia. According to respondents opinion, more than a half of buildings hasn't achieve the desired quality. 
Nowadays in the world, there is a variety of certification systems evaluating the sustainability of buildings. However, in Slovakia, there are only few projects, in particular developer projects that have granted such certificates. According to Malovec (2012) it is the group of construction participants who are far more than other aware that green buildings, in comparison with traditional buildings, usually involve not only possibility of higher monthly hiring profit but also higher demand from customer side, longer leases, long-term low operating cost, better mix of tenants and longer lifetime.

The global trend of sustainable buildings reflects not only the requirement to reduce operating cost but also the social need for sustainable development from tenants, investors and state administration side. At last, the culture of organizations as well as the culture of concerned nation should be involved to parallel of sustainability and quality terms. In our culture, respect for the environment is not as seated as for example in Scandinavia or in neighbouring Austria.

\subsection{The Tools of Buildings Sustainability Assessment}

Even if the idea of sustainability is uniform, attitudes to sustainability assessment are disparate. This fact influenced the origin of various assessment systems. The number of the sustainability assessment methods grows every year. According to Lupíšek (2012) there can be several possible reasons: the market is still not saturated or that the existing assessment methods do not satisfy the existing needs.

Over the past 15 years, there were developed more than fifty certification systems. Although the core of any certification is the same, they can be different in view of climate, geographic location, traditions of construction technology, material base etc. In general, local evaluation methodology is used, but also in some countries the methodology of other organizations are used with corrections for specific conditions of the country. The best known and most accepted certification systems include the American LEED, British BREEAM, German DGNB or internationally recognized SBTooL.

Various assessment systems differ in demands and assessment criteria. From comparison analysis of weights of key sustainability criteria is evident that in most of all investigated systems the greatest importance is on environmental criteria. Two other sustainability criteria - economic and social - are reflected in systems by larger (economic) or smaller (social) scales (Figure 1). 


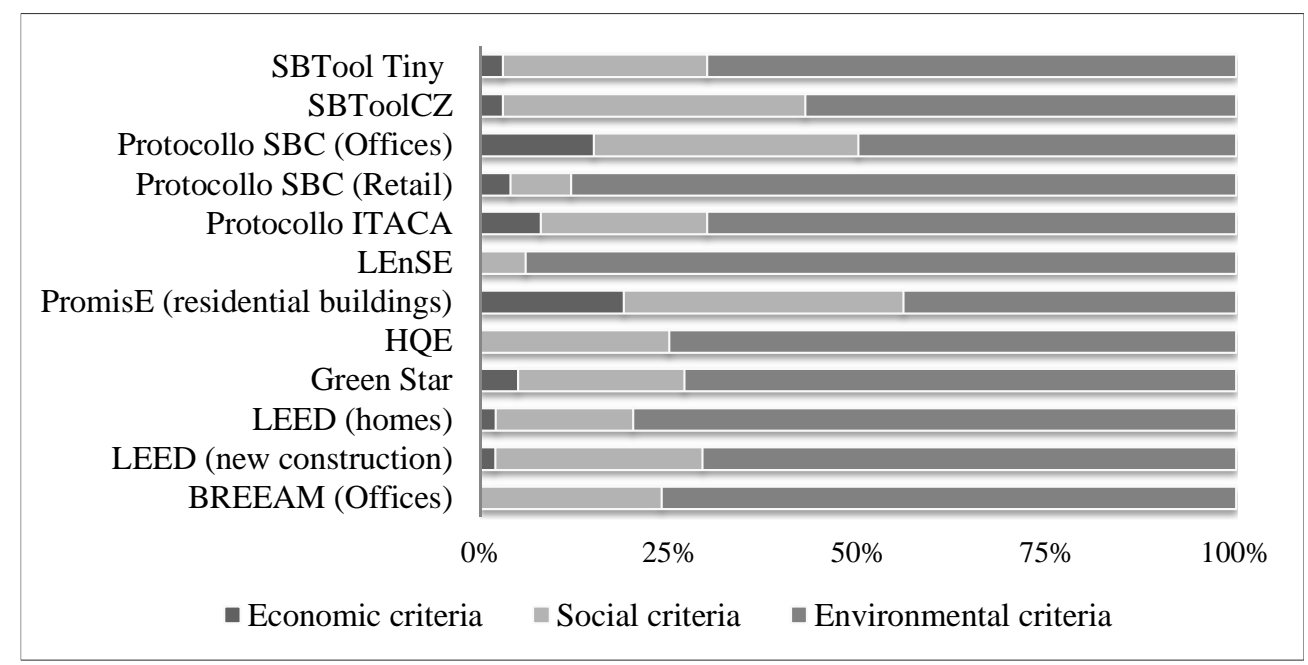

Figure 1 - Distribution of weights among groups of criteria in selected assessment systems

\subsection{The Criteria for Buildings Sustainability Assessment}

For analysis of criteria for assessment systems, there are mentioned two systems from the range of existing assessment systems that have been applied in case study assessment of the project "EcoPoint Office Center Kosice". Paradoxically, the youngest DGNB system (applied from 2010) is presented as the first. In the system have been utilized the long-term experiences of the most used predecessors, America's LEED and British BREEAM systems. Even if the DGNB system is the youngest, it is considered to be the most sophisticated and rigorous.

The DGNB (Das Gütesiegel Nachhaltiges Bauen) method of building assessment is based on the concept of integrated planning, which defines the objectives of sustainable construction already at early stage of the project. A total of 49 criteria are assessed, from which 43 criteria reflect the building quality, divided into five sections of quality: ecological, economic, socio-cultural, technical and process quality. The other criteria assess the site quality. The final assessment doesn't involve the site criteria, they are considered separately (Figure 2). 


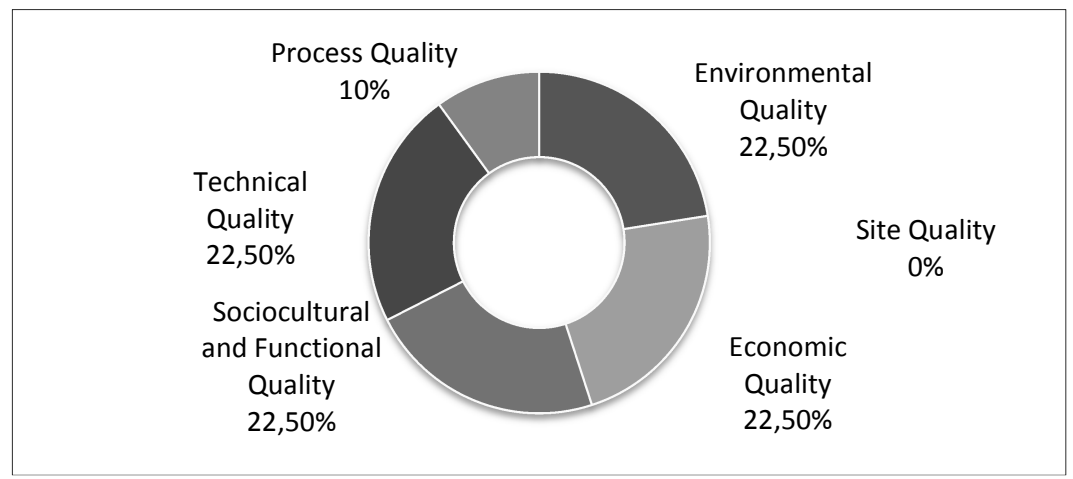

Figure 2 - The weights of fields of assessment in DGNB system

The assessment demonstrates the degree of each requirement performance. If the total performance index is at least $50 \%$, the building will receive a bronze DGNB Certificate. If the total score is at least $65 \%$, a silver certificate is granted. To qualify for a gold certificate, a project requires a total score of at least $80 \%$. Forasmuch as the DGNB aims to promote a uniform quality standard for buildings, the total score alone is not sufficient for a certificate. A certain basic level, the minimum performance index, must be reached in all the result-relevant quality sections to be able to obtain the relevant certificate. The in-process projects can obtain the pre-certificates.

LEED (Leadership in Energy \& Environmental Design) is an internationally recognized certification system developed by U.S. Green Building Council (USGBC) in 2007. Nowadays, the LEED certificate represents the sign of superior building and provides to building owner and users a certain frame of so called green building quality. The LEED promotes and reflects the overall construction approach into long-term sustainability through detection of performance in key sections. The LEED points and credits are distributed out of consideration to their potential ecological impacts. The LEED evaluates construction and technological units of buildings and their environment in categories presented in Figure 3.

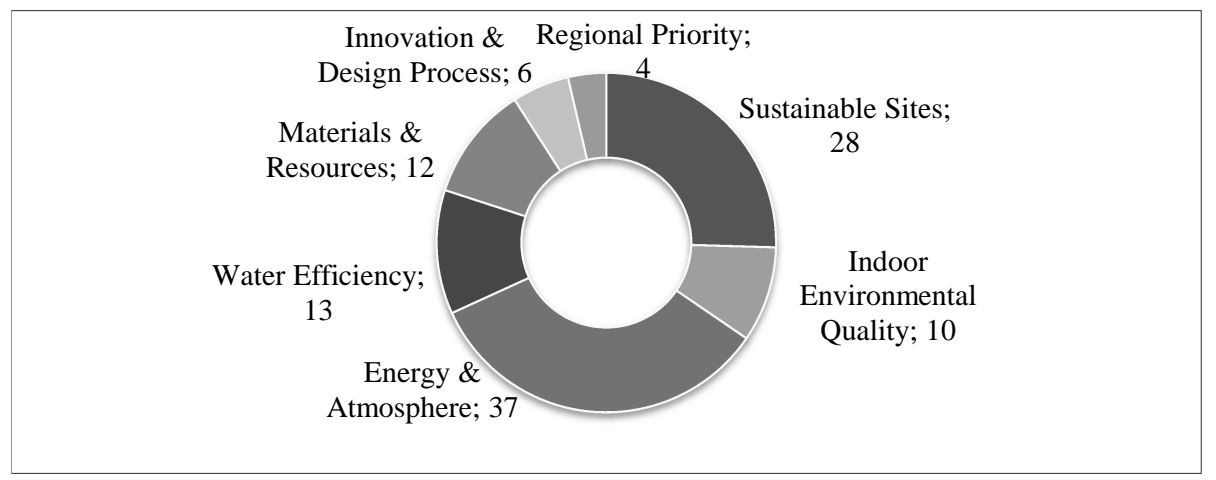

Figure 3 - The categories of sustainability and the point representation in the 


\section{LEED system}

Following achieved points, the building can obtain the four degree of certificate: bronze (40 - 49 points, statement that building was certified), silver (50 - 59 points), gold (60 - 79 points) and platinum (80 and more points).

\subsection{The Indicators of Building Sustainability}

Recently have been formed some initiatives (CESBA, 2014) to unify the assessment criteria or to develop some new concepts of the models (Srdic and Selih, 2011; Špak and Kozlovská, 2013) based on integrated approaches of quality assessment. In 2011, the collective initiative "CESBA" for a new culture of built environment in Europe has been developed. The key objective of the CESBA (Common European Sustainable Building Assessment) initiative is to develop a common European framework of building sustainability assessment in the context of quality improvement and use of existing certification tools. The vision of CESBA is "Europe where a high quality living in a sustainable built environment is the common standard practice". The summarization of indicators (according to analysed criteria in CESBA documents) is presented in Table 1. The indicators have to be taken as a reference in the development of the specific regional assessment tools.

\section{Table 1 - Reference Performance Indicators of Building Sustainability (Quality)}

\begin{tabular}{|c|c|c|}
\hline $\begin{array}{l}\text { Location, } \\
\text { territory and } \\
\text { site }\end{array}$ & \multicolumn{2}{|c|}{$\begin{array}{l}\text { - Ecological quality of site } \\
\text { - Risks at the site } \\
\text { - Circumstances at the site } \\
\text { - Options for transportation } \\
\text { - Access to amenities } \\
\text { - Access to public transport } \\
\text { - Protection or restoration of habitat on the site } \\
\text { - Adjacent infrastructures } \\
\text { - Construction site impact } \\
\text { - Bicycle parking facilities }\end{array}$} \\
\hline Process Quality & \multicolumn{2}{|c|}{$\begin{array}{l}\text { - Decision making and determination of goals } \\
\text { - Integrated Planning } \\
\text { - Planning support for energetic optimization } \\
\text { - Stakeholder involvement } \\
\text { - User involvement } \\
\text { - Evidence of Sustainability during Bid Invitation and Awarding } \\
\text { - Quality of the Executing Contractors/Pre-Qualification } \\
\text { - Quality Assurance of Construction Execution } \\
\text { - Sourcing of materials and services }\end{array}$} \\
\hline \multirow[t]{3}{*}{$\begin{array}{l}\text { Environmental } \\
\text { Quality }\end{array}$} & $\begin{array}{l}\text { Energy and } \\
\text { emissions }\end{array}$ & $\begin{array}{l}\cdot \text { Non-Renewable Primary Energy } \\
\cdot \text { Primary renewable energy } \\
\cdot \text { Specific cooling and heating demand } \\
\text { - Global Warming Potential (GWP) }\end{array}$ \\
\hline & Water & $\begin{array}{l}\cdot \text { Waste Water } \\
\cdot \text { Water Consumption }\end{array}$ \\
\hline & Waste & $\begin{array}{l}\cdot \text { Solid waste } \\
\cdot \text { Hazardous waste to disposal }\end{array}$ \\
\hline
\end{tabular}




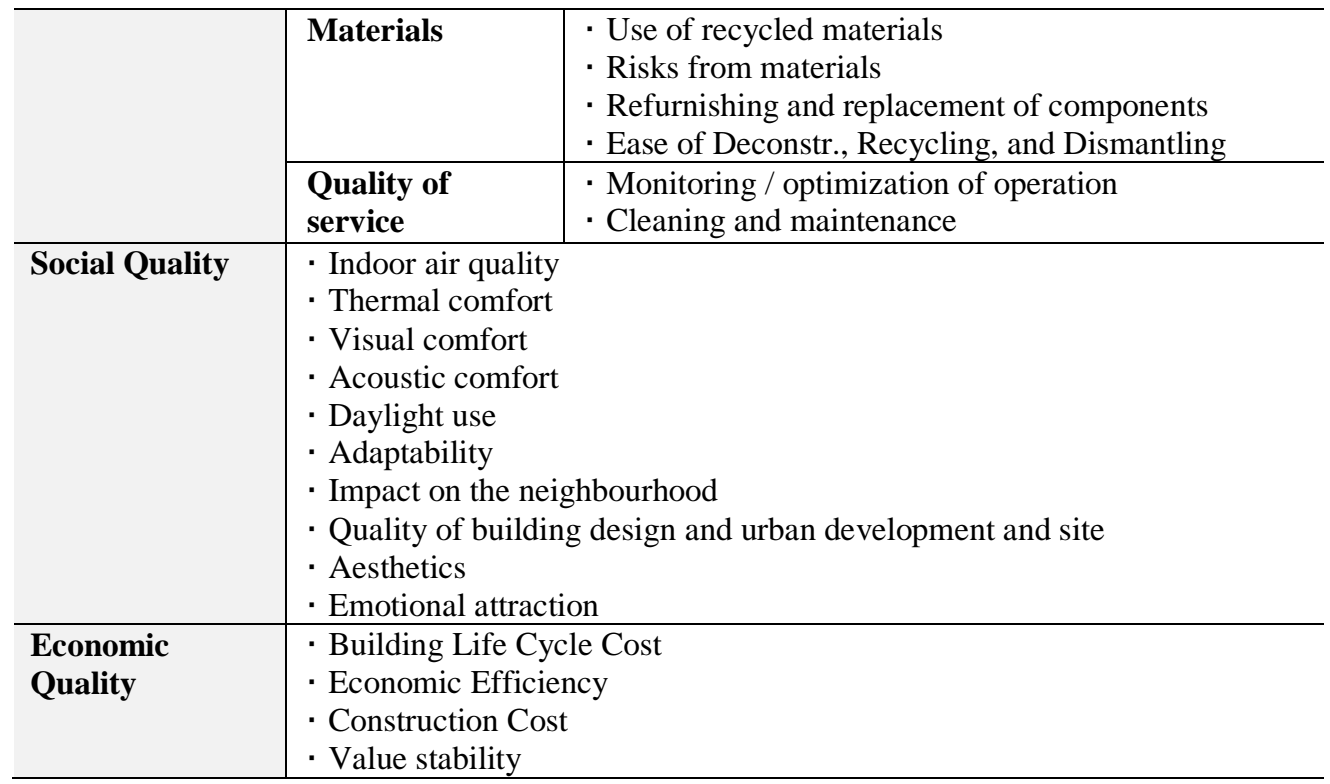

The CESBA has determined the Key Performance Indicators (KPI) intend to be a European common base for building sustainability assessment. Their adoption by the regional or national assessment systems will facilitate the communication between stakeholders and the comparability of performance results. The CESBA indicators consider the whole life cycling of the building. In Table 2 are summarized the KPI recognized (or non-recognized) in the context of life cycle stages.

Table 2 - Reference of KPI recognition within building life cycle

\begin{tabular}{l|c|c|c|c|c}
\hline \multirow{2}{*}{ Key Performance Indicators } & \multicolumn{5}{c}{ Life Cycle Stages } \\
\cline { 2 - 6 } & Production & Construction & Usage & Deconstruction & Disposal \\
\hline Non-renewable primary energy use & $\checkmark$ & $\checkmark$ & $\checkmark$ & $\checkmark$ & $\checkmark$ \\
\hline Renewable primary energy sue & $\checkmark$ & $\checkmark$ & $\checkmark$ & $\checkmark$ & $\checkmark$ \\
\hline $\mathrm{CO}_{2}$ emissions & $\checkmark$ & $\checkmark$ & $\checkmark$ & $\checkmark$ & $\checkmark$ \\
\hline Indoor air quality & $\mathbf{x}$ & $\mathbf{x}$ & $\checkmark$ & $\mathbf{x}$ & $\mathbf{x}$ \\
\hline Thermal comfort & $\mathbf{x}$ & $\mathbf{x}$ & $\checkmark$ & $\mathbf{x}$ & $\mathbf{x}$ \\
\hline Building Life Cycle cost & $\checkmark$ & $\checkmark$ & $\checkmark$ & $\checkmark$ & $\checkmark$ \\
\hline Reused/recycled materials & $\checkmark$ & $\checkmark$ & $\checkmark$ & $\checkmark$ & $\checkmark$ \\
\hline Water consumption & $\checkmark$ & $\checkmark$ & $\checkmark$ & $\checkmark$ & $\checkmark$ \\
\hline Solid waste & $\checkmark$ & $\checkmark$ & $\checkmark$ & $\checkmark$ & $\checkmark$ \\
\hline User involvement & $\mathbf{x}$ & $\mathbf{x}$ & $\checkmark$ & $\mathbf{x}$ & $\mathbf{x}$ \\
\hline Monitoring of operation & $\mathbf{x}$ & $\mathbf{x}$ & $\checkmark$ & $\mathbf{x}$ & $\mathbf{x}$ \\
\hline
\end{tabular}




\section{SUSTAINABILITY INDICATORS OF "ECOPOINT OFFICE CENTER KOSICE" - CASE STUDY}

EcoPoint Office Center Košice is one from few sustainable buildings in Slovakia. Its sustainability was declared by certificate since design phase of the project.

\subsection{The Building Description}

The administrative centre (Figure 4) is located in the close proximity of main traffic artery, nearby exit and entry to Košice city. It is designed as the set of three separate $5-6$ storey buildings with floor plan of the letter L. The first phase - the building SO 01 (the volume $38,279 \mathrm{~m}^{3}$ ) - is already constructed. Bearing structures consist of reinforced concrete basement walls, reinforced concrete frame, reinforced ceilings without girders and reinforced external walls.

The roof coat was designed as non-breather with crushed gravel respectively with garden arrangements as green roofs. The building is based on footings, combined with vibrated gravel and reinforced concrete piles. The heating system involves two ground-water heat pumps. Thirty geothermal piles with the length of $130 \mathrm{~m}$ serve as the primary source for heat pumps as well as the cooling source for heating/cooling system. There is the innovative heating and cooling system using activation of the concrete core in ceilings with in-built distribution chain.
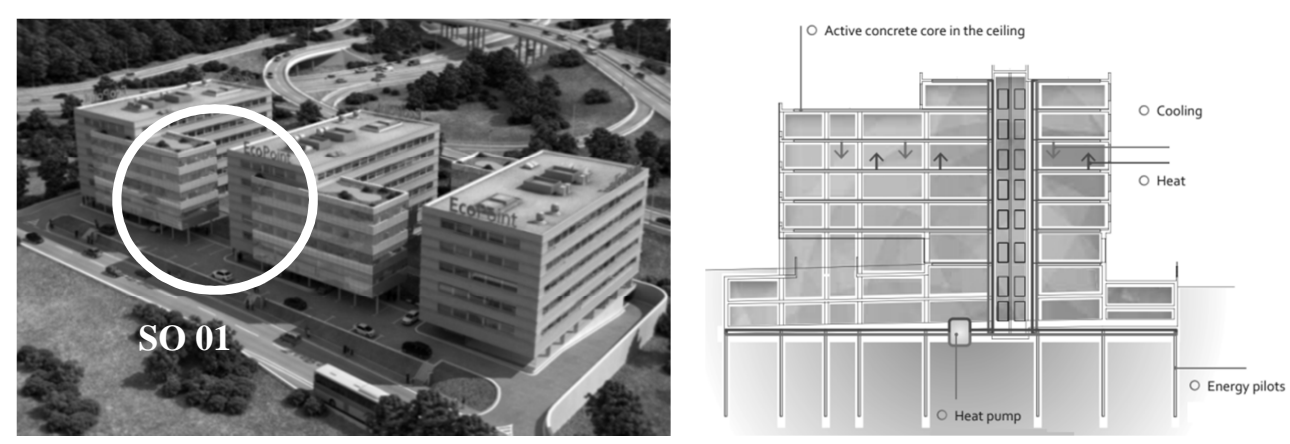

Figure 4 - EcoPoint Office Center Košice (www.ecopoint.sk)

\subsection{The Process of the Building Project Certification}

The German company Bischoff \& Compagnons after several years' plans in 2012 started with construction of the first building in the project EcoPoint Office Center Kosice. At the beginning of the design phase, the project has been assessed by the system DGNB and as the first building project in Slovakia has been awarded with Silver DGNB Pre-certificate. During construction, also due to better provided consultancy background in Slovakia, the investor decided for certification in the LEED system. The project has been assessed according to criteria for New Construction (Table 3). 
Table 3 - LEED criteria for New Construction Rating System

\begin{tabular}{|c|c|c|}
\hline S & & \\
\hline $\begin{array}{l}\text { - Construction Activity } \\
\text { Pollution Prevention } \\
\text { - Site Selection } \\
\text { - Development Density \& } \\
\text { Community Connectivity } \\
\text { - Brownfield Redevelopment } \\
\text { - Alternative Transportation } \\
\text { - Site Development } \\
\text { - Storm water Design } \\
\text { - Heat Island Effect } \\
\text { - Light Pollution Reduction } \\
\text { - Tenant Design and } \\
\text { Construction Guidelines }\end{array}$ & $\begin{array}{l}\text { - Minimum IAQ Performance } \\
\text { - Environmental Tobacco Smoke } \\
\text { (ETS) Control } \\
\text { - Outdoor Air Delivery Mo } \\
\text { - Increased Ventilation } \\
\text { - Construction IAQ Management } \\
\text { Plan } \\
\text { - Low-Emitting Materials } \\
\text { - Indoor Chemical \& Pollutant } \\
\text { Source Control } \\
\text { - Controllability of Systems } \\
\text { - Thermal Comfort } \\
\text { - Daylight \& Views }\end{array}$ & $\begin{array}{l}\text { nergy Performance } \\
\text { al Refrigerant } \\
\text { ht } \\
\text { nergy Performance } \\
\text { newable Energy } \\
\text { ommissioning } \\
\text { efrigerant } \\
\text { ht } \\
\text { nt \& Verification- } \\
\text { ng } \\
\text { nt \& Verification } \\
\text { r }\end{array}$ \\
\hline Water & Mat & nno \\
\hline \multirow[t]{2}{*}{$\begin{array}{l}\text { Water Use Reduction } \\
\cdot \text { Water Efficient } \\
\cdot \text { Landscaping } \\
\cdot \text { Innovative Wastewater } \\
\text { Technologies } \\
\cdot \text { Water Use Reduction }\end{array}$} & \multirow{2}{*}{$\begin{array}{l}\text { - Storage \& Collection of } \\
\text { Recyclables } \\
\text { - Building Reuse } \\
\text { - Construction Waste } \\
\text { Management } \\
\text { - Materials Reuse } \\
\text { - Recycled Content } \\
\text { - Regional Materials } \\
\text { - Certified Wood }\end{array}$} & $\begin{array}{l}\cdot \text { Innovatic } \\
\text { Title) } \\
\cdot \text { LEED® } \\
\text { Professio }\end{array}$ \\
\hline & & Title) \\
\hline
\end{tabular}

When the project contractor has been preparing the documents to declare the LEED requirements meeting especially in the field Materials \& Resources, our institute has cooperated with him. Due to the cooperation, we could become familiar with all the process of certification and could analyse it. We have prepared the self-assessment scheme of the points as the part of preparation data for building assessment. We analysed:

- all possible points achievable in key areas,

- already achieved points arising on location of the building, its design, material and technical solutions,

- certainly not achievable points, also resulting from existing conditions and construction solutions, and

- "possible points", which can be accepted after the presentation of certificates and necessary documents.

The self-assessment indicated that in recognition of all 31 possible points, this building could be able to get a platinum certificate. On the basis of the mentioned cooperation we can state that the final assessment is difficult and the building had all prerequisites for obtaining GOLD certificate.

Several days before the paper completion the project obtained the LEED GOLD certification $(08 / 20 / 2014)$ with 73 points score (Table 4$)$. 
Table 4 - The assessment progress of EcoPoint Office Center by LEED system

\begin{tabular}{|c|c|c|c|c|c|}
\hline \multirow[t]{2}{*}{ Areas of rating system } & \multirow{2}{*}{$\begin{array}{c}\text { All } \\
\text { possible } \\
\text { Points }\end{array}$} & \multicolumn{3}{|c|}{$\begin{array}{c}\text { Self-assessment before finalizing } \\
\text { (to date } 06 / 2014 \text { ) }\end{array}$} & \multirow{2}{*}{$\begin{array}{c}\text { Credit } \\
\text { Achievement } \\
\text { 08/2014 } \\
\text { (GOLD) }\end{array}$} \\
\hline & & $\begin{array}{l}\text { Certainly } \\
\text { obtaining }\end{array}$ & \begin{tabular}{|c|} 
Certainly \\
not obtaining
\end{tabular} & $\begin{array}{l}\text { Possible } \\
\text { obtaining }\end{array}$ & \\
\hline Sustainable Sites & 28 & 22 & 1 & 4 & 22 \\
\hline Water Efficiency & 10 & 4 & 2 & 4 & 10 \\
\hline Energy \& Atmosphere & 37 & 14 & 2 & 17 & 23 \\
\hline Materials \& Resources & 13 & 3 & 9 & 1 & 6 \\
\hline Indoor Environm. Quality & 12 & 6 & 2 & 4 & 9 \\
\hline Innovation \& Design Proc. & 6 & 1 & 4 & 1 & 3 \\
\hline Regional Priority & 4 & 0 & 4 & 0 & $\mathbf{0}$ \\
\hline Total points & 110 & 50 & 24 & 31 & 73 \\
\hline
\end{tabular}

According to Green Building Information Gateway (GBIG - a product of the U.S. Green Building Council, www.gbig.org), from more than 200.000 certified buildings, the project EcoPoint Office Center Kosice belongs to top $11 \%$ of projects in this rating system version.

\subsection{The Strengths and Weaknesses of the Project Certification}

The strongest aspect of the project that motivated the investor into the certification process consisted in demonstration of the building potential in the field of Energy \& Atmosphere, through using the modern technologies in such an extent that nobody in Slovakia has not yet been used. Due to designed method of energy achievement for heating/cooling through geothermal piles, using the heat pumps and using activation of the concrete core in ceilings, the heating and cooling cost could be lower by $70 \%$ when comparing with other modern office buildings. Using the on-site renewable energy, optimizing energy performance and a number of operational procedures for systems measurement and control represented the main assumption for achievement of the best sustainability evaluation of the project.

Moreover, one of the strengths of the project is its location. In area on sustainable site the project gained the most points from all possible ( 22 from 28 points). The project is situated right on the main highway exit to Košice from Prešov. It is a perspective location, one of the most supported development areas in Košice in future, easy and trouble-free access by car and public transport with shopping centres in the surrounding area.

The weaknesses of the project could be considered those at which the project cannot get points. Some of them are objectively: location is not Brownfield, cannot be used site or reuse materials, project has not regional priority, because it is commotional office space. Others have not been applied in the project: there is no proposed innovative wastewater technology, on-site renewable energy, green power technology or wood \& agrifiber products. 
In the final assessment, the U.S. Green Building Council provided the statement why is the project EcoPoint Office Center Kosice "green" (presented in Table 5).

Table 5 - Why is EcoPoint Office Center Kosice "green"

\begin{tabular}{|c|c|}
\hline Water Efficiency & $\begin{array}{l}40 \% \text { reduction in baseline indoor water use } \\
100 \% \text { reduction in potable landscape water use }\end{array}$ \\
\hline Energy \& Atmosphere & $34 \%$ improvement on baseline building performance rating \\
\hline $\begin{array}{l}\text { Indoor Environmental } \\
\text { Quality }\end{array}$ & $\begin{array}{l}90 \% \text { of occupied space has quality views } \\
75 \% \text { of occupied space has day lighting }\end{array}$ \\
\hline Materials \& Resources & $\begin{array}{l}75 \% \text { diversion of construction and demolition debris } \\
20 \% \text { recycled content building materials } \\
20 \% \text { regionally extracted, recovered or manufactured materials }\end{array}$ \\
\hline
\end{tabular}

\section{CONCLUSION}

The main principles of sustainability in area of ecology, effectiveness, self regulation and self-supporting, reasonable sufficiency, preventive care and predictability, respecting the needs and rights of future generations or socially, ethically and environmentally friendly economy, decision making, management and behaviour are reflected also in construction assessment field.

There are analysed the evaluation and certification systems that assess buildings sustainability based on various criteria. From comparison analysis of weights of key sustainability criteria is evident that in most of all investigated systems the greatest importance is on environmental criteria. Two other sustainability criteria - economic and social - are reflected in systems by larger (economic) or smaller (social) scales.

In the paper are directly declared the parallels between sustainability criteria and quality within evaluation areas of different systems (Environmental Quality, Economic Quality, Socio-cultural and Functional Quality, Technical Quality, Process Quality, Site Quality). The sustainable principles applicability increasingly relates on technical innovations that also present one from evaluation criteria.

The approaches into performance of sustainability criteria are declared through the case study of the building EcoPoint Office Center Košice. There are confirmed the possibilities of several assessment systems using. While in preconstruction phase the building has been awarded with Silver DGNB Precertificate, during construction the building has been assessed in the LEED system. The self-assessment of the building, conducted during the building lifecycle allowed to uncover the weaknesses of the project certification. The final assessment of the building entailed the LEED GOLD certification with 73 points score, from 110 ultimate points. According to Green Building Information Gateway, from more than 200.000 certified buildings, the project EcoPoint Office Center Kosice belongs to top $11 \%$ of projects in this rating system version. 
Moreover, the results has indicated the real benefits of the sustainable building. The benefits involve the meaning improvements and savings in field of Water Efficiency, Energy \& Atmosphere, Indoor Environmental Quality and Materials $\&$ Resources. The most significant are presented by $40 \%$ reduction in baseline indoor water use, $100 \%$ reduction in potable landscape water use, $75 \%$ diversion of construction and demolition debris.

The results are destined for potential investors perhaps even for present owners that have ambitions and responsibility for building sustainability principles performance when designing and using their properties.

\section{ACKNOWLEDGEMENT}

The article presents a partial research result of the project VEGA - 1/0677/14 "Research of construction efficiency improvement through modern method of construction" supported by Scientific Grant Agency VEGA of Slovak Republic.

\section{REFERENCES}

CESBA, 2014. A Collective Initiative for a New Culture of Built Environment in Europe. [online] Available at: http://www.slideserve.com/tuwa/a-collectiveinitiative-for-a-new-culture-of-built-environment-in-europe [Accessed 6 July 2014].

Cole, R.J., 2005. Building environmental assessment methods: Redefining intentions and roles. Building Research and Information, 33(5), pp.455-467.

Government of Slovak Republic, 2001. Proposal of National Strategy for Sustainable Development. [online] Bratislava: Government of SR. Available at: http://www.rokovania.sk/Rokovanie.aspx/BodRokovaniaDetail?idMaterial=1394 0 [Accessed 3 August 2014] (in Slovak).

Ding, G.K.C., 2008. Sustainable construction-The role of environmental assessment tools. Journal of Environmental Management, 86(3), pp.451-464.

Haapio, A. and Viitaniemi, P., 2008. A critical review of building environmental assessment tools. Environmental Impact Assessment Review, 28(7), pp.469-482.

Heinonen, J., Junnila, S., 2014. Residential energy consumption patterns and the overall housing energy requirements of urban and rural households in Finland. Energy and Buildings, 76(6), pp.295-303.

Kim, J-L, Greene, M., Kim, S., 2014. Cost Comparative Analysis of a New Green Building Code for Residential Project Development. Journal of construction engineering and management, 140(5).

Květoň, V., Louda, J., Slávik, J., Pelucha, M., 2014. Contribution of Local Agenda 21 to Practical Implementation of Sustainable Development: The Case of the Czech Republic. European Planning Studies, 22(3), pp.515-536. 
Lupíšek, A., 2012. Building sustainability assessment system corresponding to needs of users. In: The 3rd International Symposium on Life-Cycle Civil Engineering, Vienna, Austria, pp.1802-1806.

Lupíšek, A., Hájek, P., Pavlu, T. and Hakinen, T., 2010. Sustainability and performance assessment and benchmarking of buildings. In: Proceedings of Conference on Central Europe towards Sustainable Building Location, Prague, Czech Republic, 2010, pp.583-584.

Malovec, M., 2012. Green Building Mathematics. TZB HAUSTECHNIK, 20(4), pp.22 - 24 (in Slovak)

Singh, R.K., Murty H.R., Gupta, S. K. and Dikshit, A. K., 2012. An overview of sustainability assessment methodologies. Ecological Indicators, 15(1), pp.281299.

Sharifi, A. and Murayama, A., 2013. A critical review of seven selected neighborhood sustainability assessment tools. Environmental Impact Assessment Review, 38(1), pp.73-87.

Srdic, A. and Selih, J., 2011. Integrated quality and sustainability assessment in construction: a conceptual model. Technological and economic development of economy, 17(4), pp.611-626.

Stankeviciute, L. and Criqui, P., 2008. Energy and climate policies to 2020: The impacts of the European "20/20/20" approach. International Journal of Energy Sector Management, 2(2), pp.252-273.

Špak, M. and Kozlovská, M., 2013. The concept of a comprehensive assessment of building structures. In: Multi-dimensional approaches supporting integrated design and management of construction projects. Proceedings of scientific papers. Košice: Technical University of Košice, Faculty of Civil Engineering, pp.174-180.

Župová, L. and Kozlovská, M., 2013. Modern methods of construction as a challenge for energy efficiency buildings. In: SGEM 2013 International Multidisciplinary Scientific GeoConference Surveying Geology and Mining Ecology Management, Albena, Bulgaria, 2013, pp.677-684.

Tasios, N., Apostolaki, E., Capros, P. and De Vita, A., 2013. Analyzing the bioenergy supply system in the context of the 20-20-20 targets and the 2050 decarbonization targets in the EU. Biofuels, Bioproducts and Biorefining, 7(2), pp.126-146. 


\section{ABOUT THE AUTHORS}

Mária Kozlovská is a professor at the Institute of Construction Technology and Management of the Faculty of Civil Engineering, TUKE - Technical University of Košice, Slovak Republic, e-mail: maria.kozlovska@tuke.sk.

Zuzana Struková is an assistant professor at the Institute of Construction Technology and Management of the Faculty of Civil Engineering, TUKE Technical University of Košice, Slovak Republic, e-mail: zuzana.strukova@tuke.sk.

Alena Tažiková is an assistant professor at the Institute of Construction Technology and Management of the Faculty of Civil Engineering, TUKE Technical University of Košice, Slovak Republic, e-mail: alena.tazikova@tuke.sk. 